\title{
Posterior Epidural Migration of a Sequestered Lumbar Intervertebral Disc Fragment
}

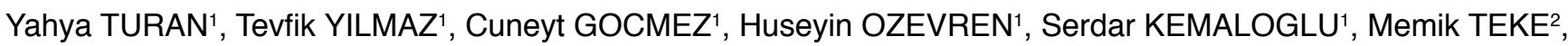 \\ Mustafa Akif SARIYILDIZ ${ }^{3}$, Adnan CEVIZ' ${ }^{1}$, Cuneyt TEMIZ ${ }^{4}$
}

${ }^{1}$ Dicle University, School of Medicine, Department of Neurosurgery, Diyarbakır, Turkey

${ }^{2}$ Dicle University, School of Medicine, Department of Radiology, Diyarbakır, Turkey

${ }^{3}$ Dicle University, School of Medicine, Department of Physical Medicine and Rehabilitation, Diyarbakır, Turkey

${ }^{4}$ Celal Bayar University, School of Medicine, Department of Neurosurgery, Manisa, Turkey

\section{ABSTRACT}

AIM: Posterior epidural migration of a sequestered lumbar intervertebral disc fragment (PEMSLIDF) is an extremely rare condition published so far only as case reports or small case series (ranging between 2 to 8 cases). Diagnosing this condition is often challenging and the diagnosis is usually made intraoperatively. The affected patients usually suffer cauda equina syndrome (CES). In the present study, we aimed to discuss the clinical and radiological findings, types and features of surgical therapies, and outcomes of 9 patients with PEMSLIDF.

MATERIAL and METHODS: This study included 9 (0.36\%) patients with PEMSLIDF among 2470 patients who underwent lumbar disc hernia surgery between August 2002 and September 2012. The preoperative clinical and radiological properties of the patients were evaluated. The postoperative outcomes were assessed using neurological examination, radiological imaging, visual analog scale (VAS) and modified Odom criteria.

RESULTS: RESULTS: As far as we know, this study is the largest case series examining the characteristics of PEMSLIDF. Seven $(77.8 \%)$ of our patients were male and 2 (22.2\%) were female and they had a mean age of 49.5 years (range 28-70 years). The mean duration from symptom onset to hospital admission was 7.4 days. Seven patients had CES. All patients underwent sequestrectomy and discectomy via posterior microsurgery. The patient outcomes were evaluated by the Modified Odom criteria and the outcome was excellent in two (22.2\%) patients, good in 4 (44.5\%), fair in $2(22.2 \%)$, and poor in $1(11.1 \%)$.

CONCLUSION: The entire free fragment can usually be excised via the posterior microsurgery technique. Early surgical treatment is of great importance to prevent more serious neurological deficits.

KEYWORDS: Cauda equina syndrome, Sequestered intervertebral disc, Posterior epidural migration, Lumbar disc herniation, Spinal surgery

\section{INTRODUCTION}

ombardi reported the first posterior epidural migration of a sequestered lumbar intervertebral disc fragment (PEMSLIDF) case in 1973 (33). Lumbar disc herniation $(\mathrm{LDH})$ can theoretically migrate in virtually any direction in the spinal canal, and superior, inferior, lateral, interdural, and intradural migrations have all been described $(2,3,8,28,35,40$, $45,46,57)$. Nevertheless, a herniation with posterior epidural migration away from the site of extrusion has been only rarely reported (12). Patients with the latter condition may have serious neurological deficits. The radiological examinations reveal a lesion appearance that is similar to other mass lesions 
Turan Y. et al: Posterior Epidural Migration of Lumbar Disc

of the lumbar region. As far as we know, our 9-case series of PEMSLIDF represents the largest to date. A detailed literature search yielded 60 cases with similar features since the original description of the condition $(1,6,8-10,12,14,15,17,19,20,22$, $24-34,36,37,41-43,45,47-54)$. This study aimed to assess the clinical and imaging properties of PEMSLIDF and to discuss its surgical treatment and postoperative outcomes.

\section{MATERIAL and METHODS}

A total of 2470 patients underwent LDH surgery in our department from August 2002 to September 2012. Nine $(0.36 \%)$ of them were diagnosed with PEMSLIDF and underwent a surgical operation for that condition. Sex, age, symptom duration, neurological and radiological findings, disc level, and postoperative outcome were recorded for each patient.

One patient was diagnosed by computed tomography (CT) rather than magnetic resonance imaging (MRI) due to having an MRI-incompatible pelvic prosthesis. The remainders of the patients were diagnosed with the help of MRI. All patients were immediately operated with sequestrectomy and discectomy via posterior microsurgery after establishing the diagnosis. It was observed that compression on dura and nerve roots was relieved and decompression was achieved after sequestrectomy and discectomy. None of the patients were applied spinal instrumentation. The patients were both clinically and radiologically evaluated at the postoperative period. The postoperative outcomes were assessed with the help of Modified Odom criteria (Table I) and visual analog scale (VAS) (38). Each patient generally underwent a followup examination within 3 months of surgery. The follow-up examinations were performed at $6^{\text {th }}$ and $12^{\text {th }}$ months when patients reported no symptoms during follow-up. The patients were followed for a mean duration of 24.4 months (range 12 months 3 years).

\section{RESULTS}

Seven $(77.8 \%)$ of our patients were male and $2(22.2 \%)$ were female. Their mean age was 49.5 years (range 28-70 years). The mean duration between symptom onset and hospital admission was 7.4 days (range 2-21 days). All patients had severe symptoms, with 7 patients having cauda equina syndrome (CES) and 2 having radicular syndrome.

PEMSLIDF was diagnosed with the help of CT in one patient due to having an MRI-incompatible pelvic prosthesis. The remaining patients were diagnosed by MRI. The MRI appearance of PEMLIF was iso/hypointense on T1-weighted images and of variable intensity on T2-weighted images. According to the radiological imaging data, 4 (44.5\%) patients had PEMSLIDF at the level of L3-4, $3(33.3 \%)$ at the level of L4-5, 1 at the level of L5-S1, and $1(11.1 \%)$ at the level of L2-3. MRI examination of 6 patients visualized a tumor-like contrast uptake in an annular pattern around the free disc fragment. Its localization was at the right posterolateral space in 4 patients, left posterolateral space in 4, and median in 1.

After establishing the diagnosis, all patients were urgently operated with sequestrectomy and discectomy via the posterior microsurgery technique (Figure 2A-D). The compression on dura and nerve roots was removed and these structures were decompressed after sequestrectomy and discectomy. None of the patients underwent spinal instrumentation. No patient developed intraoperative complications such as dural laceration or cerebrospinal fluid (CSF) leakage.

The patients were periodically followed clinically by neurological examination, primarily for sphincter functions, and radiologically by performing imaging tests. Their postoperative outcomes were assessed according to the Modified Odom Criteria (38) and VAS. Each patient underwent a follow-up examination within the first 3 months after surgery. The later follow-up visits were at the $6^{\text {th }}$ and $12^{\text {th }}$ months as long as the patients did not experience any problem. The mean follow-up duration after surgery was 24.4 months (range 12 months to 3 years). According to the Modified Odom Criteria, an excellent result was achieved in $2(22.2 \%)$ patients, a good result in $4(44.5 \%)$, a fair result in $2(22.2 \%)$, and a poor result in $1(11.1 \%)$. The two most important factors that affected the patient outcomes were the time from symptom onset to surgery and whether CES was partial or not. As such, partial CES that was operated within 3 days or less was associated with a better outcome. The clinical findings of the patients are summarized on Table II.

Of the 7 cases of CES, 3 were prominent and 4 were partial. The Odom criteria indicated that 1 of 3 patients with prominent CES had an excellent outcome, 1 had a good outcome, and 1 had a fair outcome. Of the 4 patients with partial CES, on the other hand, three had a good outcome and $1 \mathrm{had}$ an excellent outcome. Patients complaining of urinary incontinence were assessed by urological examination early after surgery. Urinary incontinence existed in 7 out of 9 patients in the preoperative

Table I: Modified Odom Criteria (38)

\begin{tabular}{ll}
\hline Grade & Definition \\
\hline excellent & all preop symptoms relieved, patient is able to perform daily occupations \& activities without impairment \\
\hline good & $\begin{array}{l}\text { minimal persistence of preop symptoms, patient is able to perform daily occupations \& activities without } \\
\text { significant interference }\end{array}$ \\
\hline fair & relief of some preop symptoms, but daily occupations \& activities remain significantly limited \\
\hline poor & symptoms \& signs unchanged or worse \\
\hline
\end{tabular}


period. Surgery benefited urinary incontinence in $6(85.7 \%)$ of them. The only patient with residual incontinence underwent bladder reconstruction and intermittent catheterization. Among the two patients with radiculopathy who had a fair and a good outcome respectively as assessed by the Odom criteria, one was started on physical therapy program for paresis.

This study is the largest case series assessing the characteristics of PEMSLIDF. Since the original description by Lombardi in 1973, a total of 74 patients (mean age 53.11 years) including our 9 cases of whom $57(77.02 \%)$ were male and $17(22.98 \%)$ were female were reported in the English literature $(1,6,8-$ $10,12,14,15,17,19,20,22,24-34,36,37,41-43,45,47-54)$. Clinically, $38(51.35 \%)$ of the 74 patients had CES, $30(40.54 \%)$ had radicular pain, and $6(8.11 \%)$ had lumbago. To determine the disc localization, MRI was used in 57 (77.02\%) patients. PEMLIF had an iso/hypointense appearance on T1-weighted images while it appeared with variable intensity on T2-weighted images. Gadolinium contrast application made $85.71 \%$ of the lesions acquire a peripheral ring-like contrast uptake pattern. According to radiological imaging results, the PEMSLIDF level was L1-2 in 2 (2.7\%) patients, L2-3 in 12 (16.2\%), L3-4 in 29 (39.2\%), L4-5 in 24 (32.4\%), and L5-S1 in 7 (9.5\%). Despite some missing elements in the records of 2 patients, and considering that the terminology used by each author to assess outcomes is different, an assessment of the surgical outcomes of 72 patients revealed that $53(73.62 \%)$ patients had total recovery, $3(4.17 \%)$ had subtotal recovery, $15(20.83 \%)$ showed improvement, and 1 (1.38\%) had unchanged clinical signs. The data of all reported cases are shown on Table III.

\section{Illustrative Cases}

Case 1: A 41-year-old man presented with intermittent lower back pain for 5 years and urinary incontinence, bilateral leg pain with the left-sided pain being more intensive, mild weakness, and numbness for 3 days. Neurological examination revealed mild weakness in foot dorsiflexion and plantar flexion as well as bilateral hypoesthesia in the L5, S1 dermatomes. Patellar and Achilles reflexes were absent in both lower extremities. Reduced anal tonus and perianal sensory loss were also noted. MRI showed a sequestered disc fragment at the level of L4-L5, which almost completely filled spinal canal and compressed the dural sac from its posterior aspect (Figure $1 \mathrm{~A}-\mathrm{C})$.

Preoperative VAS scores for both leg and back pain were 8. The patient was taken to urgent posterior microsurgery operation. Following left hemilaminectomy and flavectomy, a sequestered disc fragment localized to the left posterolateral region, which compressed the dura and nerve root, was visualized (Figure 2A-D). Sequestrectomy and discectomy were then performed and the dura and nerve root were decompressed. No postoperative complication occurred.

Urinary incontinence abated early in the postoperative course (on the $7^{\text {th }}$ day). Motor functions on neurological examination also recovered and the quality of life was improved three months after the operation. VAS scores for leg and back pain were 1 and 2, respectively. Postoperative follow-up lumbar MRI revealed no pathological finding with the exception of mild granulation tissue at the area of the operation (Figure 3AC).

Case 2: A 32-year-old woman presented to our hospital with sudden-onset, excruciating low back pain, bilateral leg pain more severe on the right-side, and urinary incontinence for 5 days. She gave a history of intermittent low back pain for 6 months that had partially responded to medical therapy. On neurological examination, the straight leg raising test was $30^{\circ}$ positive on the right side and $45^{\circ}$ on the left side. There were also loss of Achilles reflex, hypoesthesia corresponding to the L5 and S1 levels, and perianal sensory loss. Lumbar $\mathrm{MRI}$ demonstrated a sequestered disc fragment with posterior localization at the level of L5-S1, which almost completely filled the spinal canal and compressed the dural sac (Figure $4 \mathrm{~A}-\mathrm{C})$. The mass lesion had contrast uptake in a ring-like pattern (Figure 4-C).

Table II: Summary of Clinical Findings and Outcomes of 9 Patients with PEMSLIDF

\begin{tabular}{|c|c|c|c|c|c|c|c|c|c|c|}
\hline $\begin{array}{l}\text { Case } \\
\text { No }\end{array}$ & $\begin{array}{c}\text { Age } \\
\text { (Yrs), } \\
\text { Sex }\end{array}$ & Radiculopathy & CES & $\begin{array}{l}\text { Duration of } \\
\text { Symptoms }\end{array}$ & $\begin{array}{c}\text { Imaging } \\
\text { Diagnostic } \\
\text { Device }\end{array}$ & $\begin{array}{l}\text { Lumbar } \\
\text { Level }\end{array}$ & \multicolumn{2}{|c|}{ VAS† (preop/postop) } & $\begin{array}{c}\text { FU } \\
\text { Period }\end{array}$ & Outcome \\
\hline 1 & $41, \mathrm{M}$ & yes & partial & 3 days & MRI & L4-5 & $8 / 2$ & $8 / 1$ & $12 \mathrm{mos}$ & excellent \\
\hline 2 & $51, \mathrm{M}$ & no & yes & 2 days & MRI & L3-4 & $7 / 2$ & $7 / 2$ & $28 \mathrm{mos}$ & excellent \\
\hline 3 & $56, \mathrm{M}$ & no & yes & 2 days & MRI & L3-4 & $8 / 3$ & $7 / 2$ & 22 mos & good \\
\hline 5 & $32, \mathrm{~F}$ & yes & partial & 5 days & MRI & L5-S1 & $7 / 3$ & $7 / 2$ & $1 \mathrm{yr}$ & good \\
\hline 6 & $70, \mathrm{M}$ & no & yes & 3 wks & CT & L3-4 & $7 / 5$ & $7 / 3$ & 3 yrs & fair \\
\hline 7 & $62, \mathrm{M}$ & yes & no & 10 days & MRI & L3-4 & $8 / 6$ & $8 / 4$ & 3 yrs & poor \\
\hline 8 & $28, \mathrm{M}$ & no & partial & $1 \mathrm{wk}$ & MRI & $\llcorner 4-5$ & $8 / 3$ & $7 / 2$ & $18 \mathrm{mos}$ & good \\
\hline
\end{tabular}

CES: Cauda equina syndrome, *: According to Modified Odom criteria, FU: Follow-up, $t$ : Postoperative VAS pain scores were obtained 12 months after surgery. 
VAS scores for leg and back pain were both 7 at the postoperative period. Hemilaminectomy and flavectomy were performed on an emergent basis and the sequestered, posteriorly migrated disc material was visualized. Discectomy was also added to the emergency sequestrectomy. At the end of the operation, the dural sac and nerve root were freed of the compression. Neurological examination at the 2-month follow-up revealed full recovery and an MRI examination showed complete normalization of the anatomical structure (Figure 5A-C). Postoperative VAS scores for the lower back and leg were 3 and 2 , respectively.

\section{DISCUSSION}

The disc is sequestered in $28.6 \%$ of all cases of disc herniation. However, migration into the posterior epidural space is a fairly rare occurrence $(4,42)$. PEMSLIDF was first described by Vincenzo Lombardi (33) in 1973. Since then, a total of 74 cases including this study have been reported in the English literature.

It has been advocated by some authors that certain anatomic barriers limit the emergence of these lesions $(37,46,56)$.

Posterior migration of disc fragments is thought to be limited

Table III: Summary of Reported Cases of PEMSLIDF in the Literature Including Present Cases to Date

\begin{tabular}{|c|c|c|c|c|c|c|c|}
\hline Authors \& Year & $\begin{array}{l}\text { No. of } \\
\text { Cases }\end{array}$ & $\begin{array}{c}\text { Age } \\
\text { (Yrs), } \\
\text { Sex }\end{array}$ & $\begin{array}{c}\text { Clinical } \\
\text { Presentation }\end{array}$ & $\begin{array}{l}\text { Duration of } \\
\text { Symptoms }\end{array}$ & $\begin{array}{l}\text { Imaging } \\
\text { Diagnostic } \\
\text { Device }\end{array}$ & $\begin{array}{l}\text { Lumbar } \\
\text { Level }\end{array}$ & Outcome \\
\hline \multirow[t]{2}{*}{ Lombardi, 1973} & 2 & $58, M$ & CES & $2 \mathrm{yrs}$ & myelo & L2-3 & total recovery \\
\hline & & $54, \mathrm{M}$ & radicular pain & $2 \mathrm{mos}$ & myelo & L4-5 & total recovery \\
\hline Lichtor, 1989 & 1 & $61, \mathrm{M}$ & lumbago & $1 \mathrm{mo}$ & myelo-CT & L2-3 & total recovery \\
\hline Lutz et al., 1990 & 1 & $55, \mathrm{M}$ & radicular pain & $2 \mathrm{mos}$ & myelo-CT & L4-5 & improvement \\
\hline Hirabayashi et al., 1990 & 1 & $58, \mathrm{M}$ & CES & $4.5 \mathrm{mos}$ & myelo-CT, MRI & L3- 4 & improvement \\
\hline Sekerci et al., 1992 & 1 & $58, \mathrm{M}$ & CES & $2 \mathrm{mos}$ & myelo & L3- 4 & improvement \\
\hline Sakas et al., 1995 & 1 & $70, \mathrm{M}$ & radicular pain & 10 wks & CT & L4-5 & total recovery \\
\hline Bonaroti \& Welch, 1998 & 1 & $51, \mathrm{M}$ & CES & 2 days & MRI & L2-3 & total recovery \\
\hline Hodges et al., 1999 & 1 & $56, \mathrm{M}$ & lumbago & $1 \mathrm{wk}$ & MRI & L4-5 & asymptomatic \\
\hline \multirow[t]{2}{*}{ Neugroschl et al., 1999} & 2 & $57, \mathrm{M}$ & lumbago & 2 wks & myelo-CT, MRI & L2-3 & total recovery \\
\hline & & $64, \mathrm{M}$ & radicular pain & 2 wks & myelo-CT, MRI & L2-3 & total recovery \\
\hline Saruhashi et al., 1999 & 1 & $44, \mathrm{~F}$ & radicular pain & NR & MRI & L5-S1 & NR \\
\hline \multirow[t]{2}{*}{ Robe et al., 1999} & 2 & $68, M$ & radicular pain & acute & myelo-CT, MRI & L3- 4 & NR \\
\hline & & $41, \mathrm{~F}$ & CES & 2 wks & myelo-CT, MRI & L3- 4 & total recovery \\
\hline Lisai et al., 2000 & 1 & $63, M$ & CES & 3 days & MRI & L2-3 & total recovery \\
\hline Dosoglu et al., 2001 & 1 & $47, \mathrm{M}$ & CES & 2 wks & MRI & L3- 4 & total recovery \\
\hline \multirow[t]{3}{*}{ Eysel \& Herbsthofer, 2001} & 3 & $45, \mathrm{M}$ & CES & 8 wks & $\mathrm{CT}, \mathrm{MRI}$ & L3- 4 & total recovery \\
\hline & & $37, \mathrm{~F}$ & radicular pain & 7 wks & CT & L4-5 & total recovery \\
\hline & & $41, \mathrm{M}$ & lumbago & 11 wks & CT & L3- 4 & total recovery \\
\hline Şen et al., 2001 & 1 & $36, \mathrm{M}$ & CES & $10 \mathrm{hrs}$ & MRI & L4-5 & total recovery \\
\hline Kim et al., 2003 & 1 & $60, \mathrm{~F}$ & radicular pain & $1 \mathrm{yr}$ & MRI & L3- 4 & subtotal recovery \\
\hline \multirow[t]{3}{*}{ Kuzeyli et al., 2003} & 3 & $49, M$ & lumbago & 15 days & MRI & L4-5 & total recovery \\
\hline & & $62, \mathrm{~F}$ & CES & 25 days & CT, MRI & L1-2 & total recovery \\
\hline & & $47, \mathrm{~F}$ & CES & $4 \mathrm{mos}$ & MRI & L2-3 & total recovery \\
\hline Şenel et al., 2003 & 1 & $44, \mathrm{M}$ & lumbago & 5 days & MRI & L3- 4 & total recovery \\
\hline Kim et al., 2004 & 1 & $44, \mathrm{M}$ & CES & $6 \mathrm{hrs}$ & $\mathrm{CT}$ & L4-5 & subtotal recovery \\
\hline Walsh et al., 2004 & 1 & $62, \mathrm{M}$ & CES & 3 wks & MRI & L3- 4 & total recovery \\
\hline \multirow[t]{2}{*}{ Tatli et al., 2005} & 2 & $53, \mathrm{M}$ & CES & 2 days & MRI & L3- 4 & total recovery \\
\hline & & $54, \mathrm{M}$ & CES & 2 days & MRI & L5-S1 & improvement \\
\hline Chen et al., 2006 & 1 & $75, \mathrm{M}$ & radicular pain & 2 wks & MRI & L2-3 & improvement \\
\hline \multirow[t]{2}{*}{ Lakshmanan et al., 2006} & 2 & $58, \mathrm{M}$ & radicular pain & $1 \mathrm{mo}$ & MRI & L4-5 & total recovery \\
\hline & & $28, \mathrm{~F}$ & radicular pain & $3 \mathrm{mos}$ & MRI & L4-5 & total recovery \\
\hline
\end{tabular}


Table III: Cont.

\begin{tabular}{|c|c|c|c|c|c|c|c|}
\hline Authors \& Year & $\begin{array}{l}\text { No. of } \\
\text { Cases }\end{array}$ & $\begin{array}{c}\text { Age } \\
\text { (Yrs), } \\
\text { Sex }\end{array}$ & $\begin{array}{c}\text { Clinical } \\
\text { Presentation }\end{array}$ & $\begin{array}{l}\text { Duration of } \\
\text { Symptoms }\end{array}$ & $\begin{array}{l}\text { Imaging } \\
\text { Diagnostic } \\
\text { Device }\end{array}$ & $\begin{array}{l}\text { Lumbar } \\
\text { Level }\end{array}$ & Outcome \\
\hline Mobbs et al., 2007 & 1 & $32, \mathrm{M}$ & radicular pain & $3 \mathrm{mos}$ & MRI & L4-5 & total recovery \\
\hline \multirow[t]{2}{*}{ Choi et al., 2007} & 2 & $68, M$ & radicular pain & 3 wks & MRI & L4-5 & total recovery \\
\hline & & $74, \mathrm{~F}$ & radicular pain & 3 days & MRI & L3-4 & subtotal recovery \\
\hline \multirow[t]{2}{*}{ El Asri et al., 2008} & 2 & $42, \mathrm{M}$ & radicular pain & $1 \mathrm{mo}$ & CT & L5-S1 & improvement \\
\hline & & $36, M$ & CES & $1 \mathrm{mo}$ & $\mathrm{CT}$ & L5-S1 & improvement \\
\hline Derincek et al., 2009 & 1 & $60, \mathrm{~F}$ & radicular pain & $1 \mathrm{mo}$ & MRI & L1-2 & total recovery \\
\hline \multirow[t]{5}{*}{$\begin{array}{l}\text { Carvi y Nievas \& } \\
\text { Hoellerhage, } 2009\end{array}$} & 5 & $83, \mathrm{M}$ & radicular pain & $2 \mathrm{mos}$ & MRI & L3- 4 & total recovery \\
\hline & & $45, M$ & radicular pain & 4 wks & MRI & L4-5 & total recovery \\
\hline & & $67, \mathrm{M}$ & radicular pain & $3 \mathrm{mos}$ & MRI & L4-5 & total recovery \\
\hline & & $60, \mathrm{~F}$ & CES & $2 \mathrm{mos}$ & MRI & L5-S1 & total recovery \\
\hline & & $59, \mathrm{~F}$ & radicular pain & $4 \mathrm{wks}$ & MRI & L2-3 & total recovery \\
\hline Teufack et al., 2010 & 1 & $49, \mathrm{M}$ & radicular pain & $1 \mathrm{wk}$ & $\mathrm{CT}, \mathrm{MRI}$ & L4-5 & total recovery \\
\hline Kim et al., 2010 & 1 & $73, \mathrm{M}$ & CES & acute & CT, MRI & L4-5 & improvement \\
\hline \multirow[t]{6}{*}{ Akhaddar et al., 2011} & 6 & $60, \mathrm{~F}$ & CES & $1 \mathrm{wk}$ & MRI & L2-3 & total recovery \\
\hline & & $43, \mathrm{M}$ & CES & $2 \mathrm{mos}$ & $\mathrm{CT}$ & L5-S1 & improvement \\
\hline & & $48, \mathrm{M}$ & CES & 2 wks & MRI & L3- 4 & improvement \\
\hline & & $67, \mathrm{M}$ & radicular pain & $1 \mathrm{yr}$ & $\mathrm{CT}$ & L3- 4 & total recovery \\
\hline & & $59, \mathrm{M}$ & radicular pain & $1 \mathrm{mo}$ & $\mathrm{CT}$ & L3- 4 & total recovery \\
\hline & & $35, M$ & CES & $3 \mathrm{mos}$ & $\mathrm{CT}$ & L4-5 & improvement \\
\hline \multirow[t]{8}{*}{ Sengoz et al., 2011} & 8 & $43, \mathrm{~F}$ & CES & 3 days & MRI & L4-5 & total recovery \\
\hline & & $72, \mathrm{M}$ & CES & 1 day & $\mathrm{CT}$ & L3- 4 & total recovery \\
\hline & & $42, \mathrm{M}$ & CES & 10 days & MRI & L3- 4 & improvement \\
\hline & & $44, F$ & CES & 7 days & MRI & L3- 4 & total recovery \\
\hline & & $54, \mathrm{M}$ & CES & 3 days & MRI & L3- 4 & total recovery \\
\hline & & $55, \mathrm{M}$ & CES & 5 days & MRI & L3- 4 & total recovery \\
\hline & & $39, \mathrm{M}$ & radicular pain & 4 days & MRI & L3- 4 & improvement \\
\hline & & $34, \mathrm{M}$ & CES & 2 days & MRI & L4-5 & total recovery \\
\hline Huang et al., 2011 & 1 & $78, \mathrm{~F}$ & radicular pain & $10 \mathrm{yrs}$ & MRI & L3- 4 & total recovery \\
\hline Gonçalves et al., 2012 & 1 & $51, \mathrm{M}$ & radicular pain & 3 days & MRI & L2- 3 & total recovery \\
\hline Jove Talavera et al., 2012 & 1 & $76, \mathrm{M}$ & CES & 4 days & MRI & L3- 4 & total recovery \\
\hline \multirow[t]{2}{*}{ Rahimizadeh et al., 2013} & 2 & $53, \mathrm{M}$ & CES & 1 day & MRI & L3- 4 & total recovery \\
\hline & & $57, \mathrm{M}$ & radicular pain & NR & MRI & L4-5 & total recovery \\
\hline Tarukado et al., 2014 & 1 & $26, \mathrm{M}$ & radicular pain & $1 \mathrm{wk}$ & Myelography, MRI & L4-5 & total recovery \\
\hline \multirow[t]{9}{*}{ present study } & 9 & $41, \mathrm{M}$ & CES & 3 days & MRI & $\llcorner 4-5$ & total recovery \\
\hline & & $51, \mathrm{M}$ & CES & 2 days & MRI & L3-4 & total recovery \\
\hline & & $56, \mathrm{M}$ & CES & 2 days & MRI & L3-4 & total recovery \\
\hline & & $48, F$ & CES & 3 days & MRI & $\llcorner 4-5$ & total recovery \\
\hline & & $32, \mathrm{~F}$ & CES & 5 days & MRI & L5-1 & total recovery \\
\hline & & $70, \mathrm{M}$ & CES & 3 wks & $\mathrm{CT}$ & L3-4 & improvement \\
\hline & & $62, \mathrm{M}$ & radicular pain & 10 days & MRI & L3-4 & signs unchanged \\
\hline & & $28, M$ & CES & $1 \mathrm{wk}$ & MRI & L4-5 & total recovery \\
\hline & & $58, \mathrm{M}$ & radicular pain & $2 \mathrm{wks}$ & MRI & L2-3 & improvement \\
\hline
\end{tabular}

NR: not reported. 
Turan Y. et al: Posterior Epidural Migration of Lumbar Disc

or prevented by some anatomical structures including the sagittal midline septum, peridural membrane, the nerve root, the dura, epidural vascular structures, and epidural fat $(5,7,9$, $13,15,23,29,30,40,42,46)$. Hence, PEMSLIDF may emerge when any of these structures are defective $(11,18,52)$.

Some researchers have pointed that unusual physical movements including heavy labor, traction, spinal manipulation, and conditions of hypermobility in a patient may also facilitate
LDH migration $(36,40)$. Kim et al. (26) hypothesized that a significant contributing force on top of the ipsilateral severe adhesion of the anterior epidural space may end up with contralateral posterior epidural migration.

PEMSLIDF is more prevalent in men with a male-to-female ratio of about $4 / 1$. It more commonly involves the middle age group (mean age 53.11 years), possibly owing to altered spinal dynamics with aging $(1,15,30,42,48,52)$. The clinical
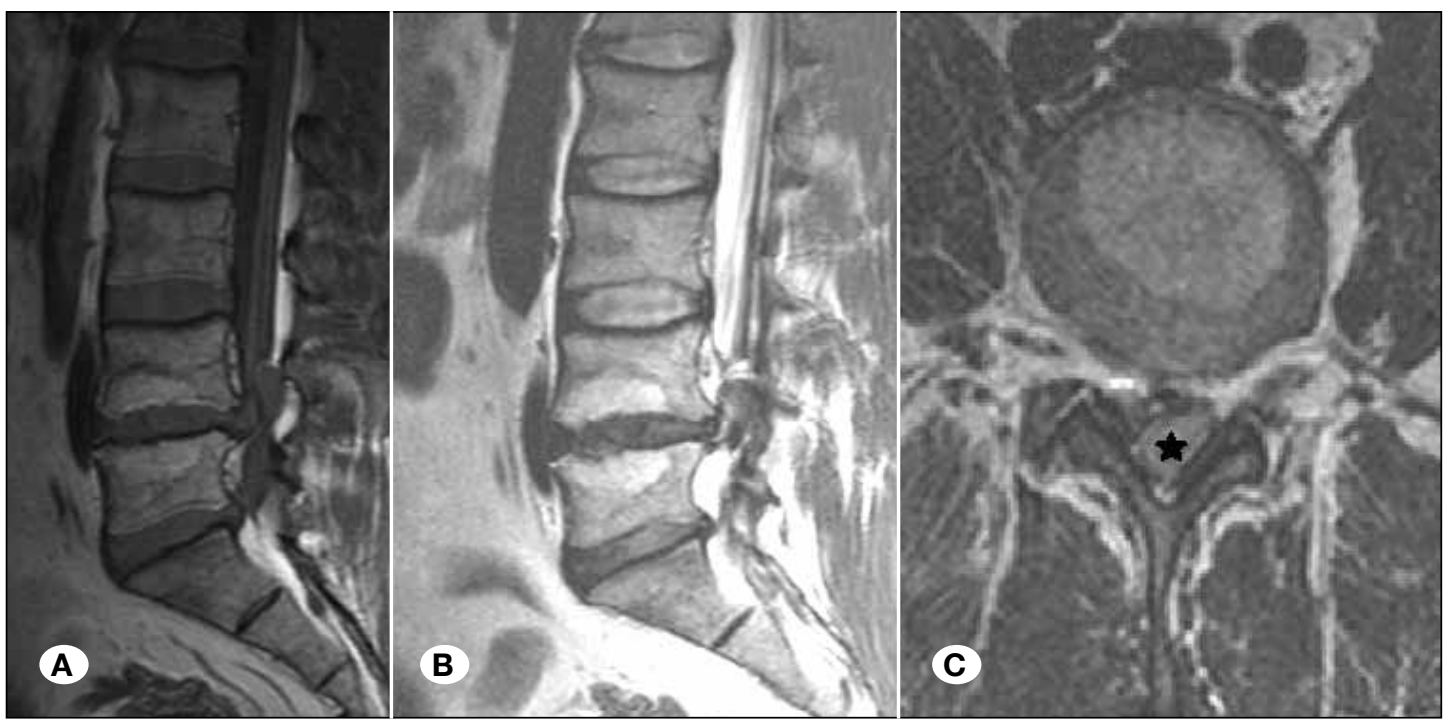

Figure 1: (Case 1)

Sagittal T1-weighted

MR image (A). Sagittal

(B) and axial (C)

T2-weighted MR

images demonstrate a sequestered fragment (asterisk) with

posterior and superior migration into the dural sac at the level of L4-5.
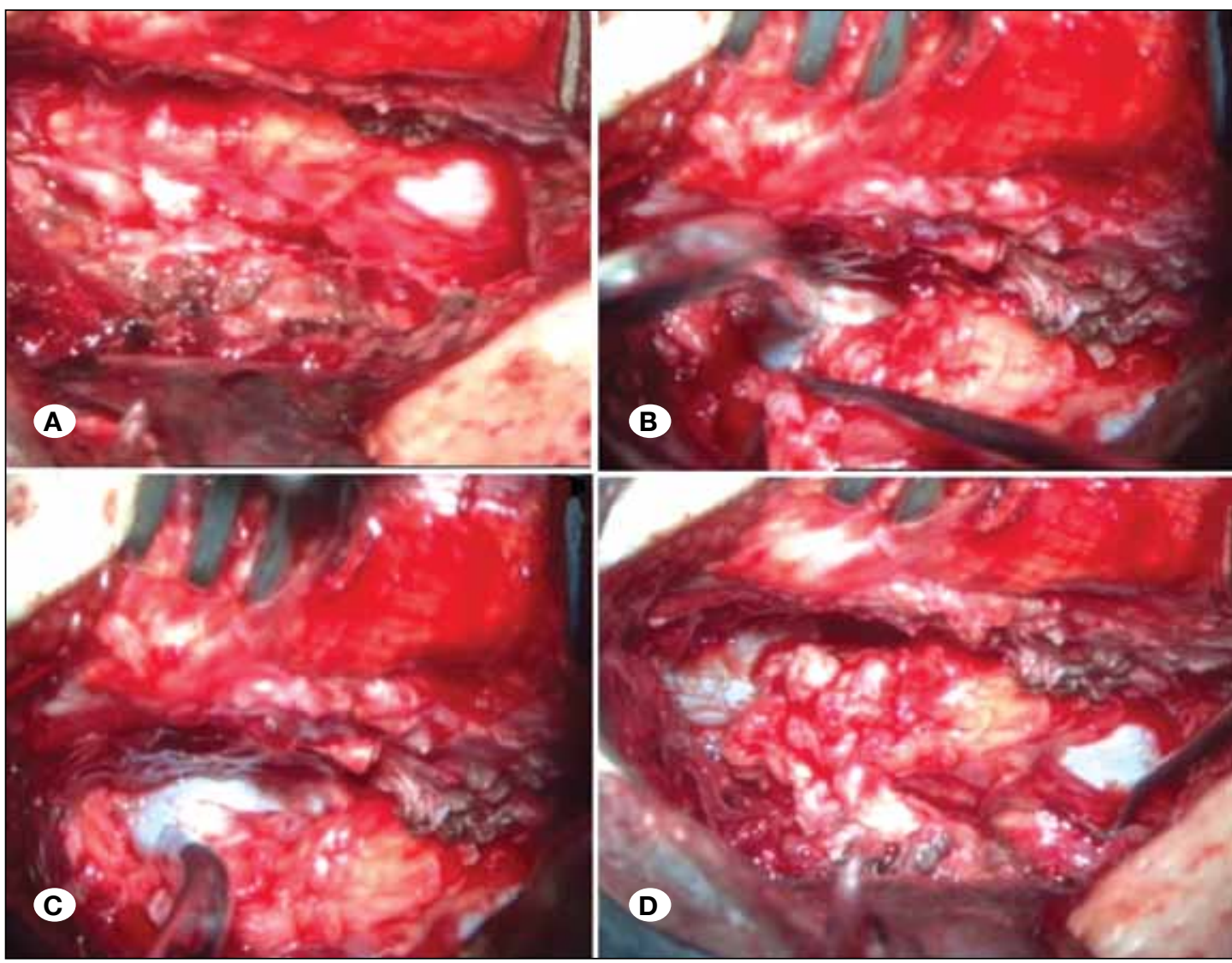

Figure 2: (Case 1)

Intraoperative images (A-D) during posterior microsurgery approach performed for the left posterolateral epidural mass (arrow) severely compressing the dural sac. 

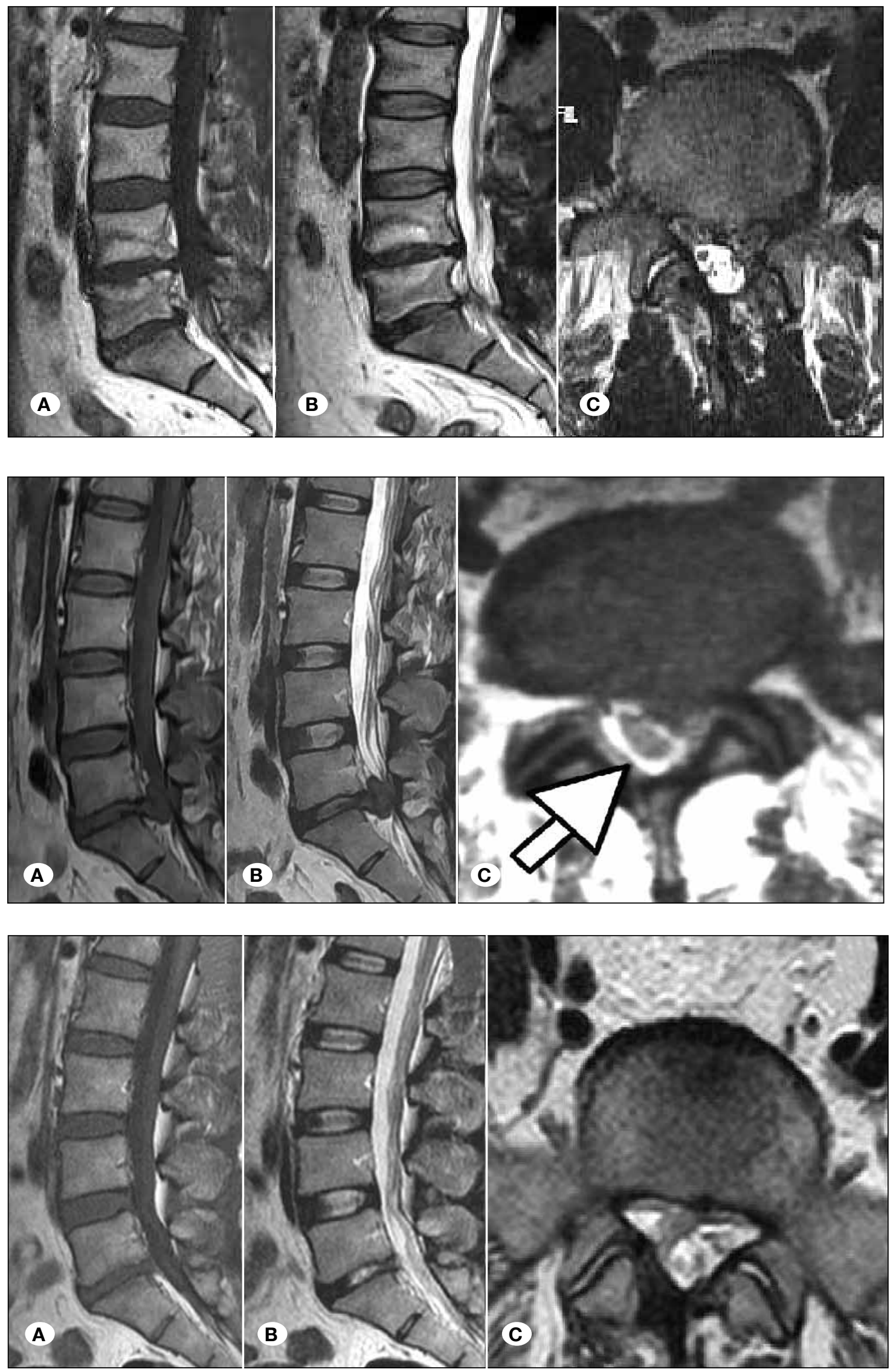

Figure 3: (Case 1)

Postoperative sagittal Tl-weighted MR image (A)

Postoperative sagittal (B) and axial (C) T2weighted MR images.

Figure 4: (Case 2)

Sagittal T1-weighted MR image (A).

Sagittal T2-weighted MR image (B). The ring-like enhancement (white arrow) is well demonstrated on the axial Gd-enhanced T1-weighted image (C).

Figure 5: (Case 2) Postoperative sagittal T1-weighted MR image (A) Postoperative sagittal (B) and axial (C) T2weighted MR images. 
Turan Y. et al: Posterior Epidural Migration of Lumbar Disc

picture of PEMSLIDF is not remarkably different from that of $\mathrm{LDH}$, although the majority $(51.35 \%)$ of cases have CES. The remaining group predominantly has clinical characteristics of radiculopathy.

MRI is the most useful radiological imaging tool for the diagnosis of PEMSLIDF. It appears isointense with the intervertebral disc on T1-weighted images. T2-weighted images, on the other hand, reveal a variable intensity of the lesion, with about $80 \%$ of all lesions appearing hypointense and the remaining $20 \%$ being isointense $(1,8,9)$. On contrastenhanced MRI images, it appears like a cyst with enhanced rims, especially if a couple of days have passed after contrast administration. The latter image characteristics are believed to be secondary to the encasement of the sequestrated disc by newly formed vessels, that is neovascularization $(8,9$, $15,30,39,42)$. However, the above-mentioned radiological appearances are not specific and they are also found in other posterior epidural lesions; thus, a definitive diagnosis can at times be made only in the operating room $(9,42)$. Clinical and radiological differential diagnoses include synovial cyst, epidural hematoma, some cartilaginous tumors such as chondrosarcoma, hemorrhagic juxtafacet cysts, gout, cystic schwannomas, primitive or metastatic epidural tumors, and abscess $(1,8,9,14-16,21,30,42-44,55)$.

Fragmented disc lesions are usually characterized by $\mathrm{Gd}$ enhancement in their periphery that is a result of inflammation and neovascularization encircling the sequestrated disc tissue $(8,9,30,39)$. It is a rare event for diffuse enhancement to appear in the lesion. Despite being extremely sensitive, MRI is not specific to such disc hernia migration.

PEMSLIDF can only be definitively diagnosed surgically by visualising the disc material after flavectomy. It is most commonly observed at the upper lumbar levels, especially at the L3-L4 level (39.2\%). This is possibly due to a different relationship between the disc and nerve root at that level than at other levels.

Surgery should be carried out without delay in patients with intense pain and neurological deficits; it is particularly important in those having cauda equina syndrome. The sequestrated disc fragment can be removed either via hemilaminectomy or laminectomy involving one or two levels, based on the lesion size $(1,15,16)$. An extra discectomy may be reasonable, particularly when a defect is present in the posterior longitudinal ligament.

Fortunately, the majority of patients suffering PEMSLIDF do well after corrective surgery. Of note, the prognosis of CES secondary to PEMSLIDF is considerably better than that resulting from an anteriorly extruded disc fragment. Thanks to a fairly large amount of epidural fat that provides suitable space at the posterior portion, most PEMSLIDF patients usually recover within weeks to a couple of months after surgery $(1,6,8,14,16)$. In the formerly published reports $53(73.62 \%)$ patients had a total recovery, $3(4.17 \%)$ had a subtotal recovery, 15 (20.83\%) showed improvement, and 1 (1.38\%) had unchanged clinical condition. PEMSLIDF should be operated early in the course to avoid serious CES or radiculopathy.

\section{- CONCLUSION}

It is rare to observe a lumbar intervertebral disc fragment migrated to the posterior epidural space, occurring mainly in the working-age population. The majority of the patients were past their middle age and the L3-L4 level was the most commonly involved level. This condition produces a nearly identical clinical picture to that of a typical LDH, although symptoms of CES are much more prevalent. Higher lumbar vertebral levels are more commonly affected. Unfortunately, this condition shares many clinical and radiological similarities with other space-occupying lesions, complicating the diagnosis. MRI features are sometimes indistinguishable from those of other various lesions. Gadolinium contrast enhancement in a ring-like pattern is typical for these lesions. Compared to typical anterior compression, CES as a result of these lesion are more favorable. Patients being operated within the first 3 days of symptoms or having symptoms consistent with partial CES usually have a favorable outcome. This special condition deserves further research to shed light on its causes, diagnosis, and management.

\section{- REFERENCES}

1. Akhaddar A, El-Asri A, Boucetta M: Posterior epidural migration of a lumbar disc fragment: A series of 6 cases. J Neurosurg Spine 15(1):117-128, 2011

2. Akhaddar $A$, Belfquih $H$, Oukabli M, Boucetta M: Posterior ring apophysis separation combined with lumbar disc herniation in adults: A 10-year experience in the surgical management of 87 cases. J Neurosurg Spine 14(4):475-483, 2011

3. Akhaddar A, Boulahroud O, Elasri A, Elmostarchid B, Boucetta M: Radicular interdural lumbar disc herniation. Eur Spine J 19 Suppl 2: S149-152, 2010

4. Baker JK, Hanson GW: Cyst of the ligamentum flavum. Spine (Phila Pa 1976) 19(9): 1092-1094, 1994

5. Bonaldi VM, Duong H, Starr MR, Sarazin L, Richardson J: Tophaceous gout of the lumbar spine mimicking an epidural abscess: MR features. AJNR Am J Neuroradiol 17(10):19491952, 1996

6. Bonaroti EA, Welch WC: Posterior epidural migration of an extruded lumbar disc fragment causing cauda equina syndrome. Clinical and magnetic resonance imaging evaluation. Spine (Phila Pa 1976) 23(3):378-381, 1998

7. Bullough PG: Pigmented villonodular synovitis and synovial cysts of the spine (comment). AJNR Am J Neuroradiol 13(1): 167-168, 1992

8. Carvi y Nievas MN, Hoellerhage HG: Unusual sequestered disc fragments simulating spinal tumors and other spaceoccupying lesions. Clinical article. J Neurosurg Spine 11(1): 42-48, 2009

9. Chen CY, Chuang YL, Yao MS, Chiu WT, Chen CL, Chan WP: Posterior epidural migration of a sequestrated lumbar disk fragment: MR imaging findings. AJNR Am J Neuroradiol 27(7): 1592-1594, 2006

10. Choi BJ, Kim DH, Park HS, Rhee DY: Posterior migration of extruded lumbar disc fragments. J Korean Neurosurg Soc 41: 137-140, 2007 
11. Chow GH, Gebhard JS, Brown CW: Multifocal metachronous epidural abscesses of the spine. A case report. Spine (Phila Pa 1976) 21(9):1094-1097, 1996

12. Derincek A, Ozalay M, Sen O, Pourbagher A: Posterior epidural mass: Can a posteriorly migrated lumbar disc fragment mimic tumour, haematoma or abscess? Acta Orthop Belg 75(3): 423427, 2009

13. Dommisse GF: Morphological aspects of the lumbar spine and lumbosacral region. Orthop Clin North Am 6(1):163-175, 1975

14. Dosoglu M, Is M, Gezen F, Ziyal Ml: Posterior epidural migration of a lumbar disc fragment causing cauda equina syndrome: Case report and review of the relevant literature. Eur Spine J 10(4):348-351, 2001

15. El Asri AC, Naama O, Akhaddar A, Gazzaz M, Belhachmi A, El Mostarchid B, Boucetta M: Posterior epidural migration of lumbar disk fragments: Report of two cases and review of the literature. Surg Neurol 70(6):668-671; discussion 671, 2008

16. Elgamri A, Sami A, Aqqad A, Hilmani S, Ibahioin K, Naja A, El Kamar A, El Azhari A: Posterior migration of a lumbar disc herniation as a cause of cauda equina syndrome. J Radiol 90(6):731-733, 2009

17. Eysel P, Herbsthofer B: Dorsal compression of the epidural cord due to free sequestral lumbar prolapse. Diagnostic problems in magnetic resonance imaging and computed tomography. Arch Orthop Trauma Surg 121(4):238-240, 2001

18. Fries JW, Abodeely DA, Vijungco JG, Yeager VL, Gaffey WR: Computed tomography of herniated and extruded nucleus pulposus. J Comput Assist Tomogr 6(5):874-887, 1982

19. Gonçalves FG, Hanagandi PB, Torres Cl, DelCarpioO'Donovan R: Posterior migration of lumbar disc herniation - imaging dilemma due to contrast contraindication: A case report. Radiol Bras 45(3):170-172, 2012

20. Hirabayashi S, Kumano K, Tsuiki T, Eguchi M, Ikeda S: A dorsally displaced free fragment of lumbar disc herniation and its interesting histologic findings. A case report. Spine (Phila Pa 1976) 15(11):1231-1233, 1990

21. Hoch B, Hermann G: Migrated herniated disc mimicking a neoplasm. Skeletal Radiol 39(12):1245-1249, 2010

22. Hodges SD, Humphreys SC, Eck JC, Covington LA: Posterior extradural lumbar disk fragment. J South Orthop Assoc 8(3): 222-228, 1999

23. Hogan QH: Lumbar epidural anatomy. A new look by cryomicrotome section. Anesthesiology 75(5):767-775, 1991

24. Huang TY, Lee KS, Tsai TH, Su YF, Hwang SL: Posterior epidural migration of sequestrated lumbar disc fragments into the bilateral facet joints: Case report. Neurosurgery 69(5): E1148-1151, 2011

25. Jove Talavera R, Altemir Martinez V, Charlez Marco A, Mas Atance J, Curia Jove E, Aguas Valiente J: Epidural posterior migration of disc fragment. Rev Esp Cir Ortop Traumatol 56(3): 224-226, 2012

26. Kim JH, Kong MH, Lee SK, Song KY: A case of posterior epidural migration of an extruded lumbar disc fragment causing cauda equina syndrome. J Korean Neurosurg Soc 35: 442-444, 2004
27. Kim JS, Lee SH, Arbatti NJ: Dorsal extradural lumbar disc herniation causing cauda equina syndrome: A case report and review of literature. J Korean Neurosurg Soc 47(3):217-220, 2010

28. Kim MS, Hur JW, Lee JW, Lee HK: Posterior and lateral epidural migration of extruded lumbar disc fragments. Case report. J Korean Neurosurg Soc 33:297-298, 2003

29. Kuzeyli K, Cakir E, Usul H, Baykal S, Yazar U, Karaarslan G, Arslan E, Peksoylu B: Posterior epidural migration of lumbar disc fragments: Report of three cases. Spine (Phila Pa 1976) 28(3):E64-67, 2003

30. Lakshmanan P, Ahuja S, Lyons K, Howes J, Davies PR: Sequestrated lumbar intervertebral disc in the posterior epidural space: A report on two cases and review of the literature. Spine J 6(5):583-586, 2006

31. Lichtor T: Posterior epidural migration of extruded lumbar disk. Surg Neurol 32(4):311-312, 1989

32. Lisai P, Doria C, Crissantu L, Dore T, Spano G, Fabbriciani C: Posterior epidural migration of an extruded free fragment from a lumbar disc herniation. J Orthop Traumatol 2:103-105, 2000

33. Lombardi V: Lumbar spinal block by posterior rotation of anulus fibrosus. Case report. J Neurosurg 39(5):642-647, 1973

34. Lutz JD, Smith RR, Jones HM: CT myelography of a fragment of a lumbar disk sequestered posterior to the thecal sac. AJNR Am J Neuroradiol 11(3):610-611, 1990

35. Masaryk TJ, Ross JS, Modic MT, Boumphrey F, Bohlman H, Wilber G: High-resolution MR imaging of sequestered lumbar intervertebral disks. AJR Am J Roentgenol 150(5):1155-1162, 1988

36. Mobbs RJ, Steel TR: Migration of lumbar disc herniation: An unusual case. J Clin Neurosci 14(6):581-584, 2007

37. Neugroschl C, Kehrli P, Gigaud M, Ragragui O, Maitrot D, Manelfe C, Dietemann JL: Posterior extradural migration of extruded thoracic and lumbar disc fragments: Role of MRI. Neuroradiology 41(9):630-635, 1999

38. Odom GL, Finney W, Woodhall B: Cervical disk lesions. J Am Med Assoc 166(1):23-28, 1958

39. Olmarker K, Blomquist J, Stromberg J, Nannmark U, Thomsen P, Rydevik B: Inflammatogenic properties of nucleus pulposus. Spine (Phila Pa 1976) 20(6):665-669, 1995

40. Quint DJ, Colon GP, Chandler WF: Quiz. Herniated, migrated disk fragment with extension into the neural foramen. AJNR Am J Neuroradiol 16(1):134, 156, 1995

41. Rahimizadeh A, Soufiani $H$, Rahimizadeh A: Posterior epidural migration of sequestered lumbar disc fragment causing cauda equina syndrome. Coluna/Columna 12(1):78-80, 2013

42. Robe P, Martin D, Lenelle J, Stevenaert A: Posterior epidural migration of sequestered lumbar disc fragments. Report of two cases. J Neurosurg 90(2 Suppl):264-266, 1999

43. Sakas DE, Farrell MA, Young S, Toland J: Posterior thecal lumbar disc herniation mimicking synovial cyst. Neuroradiology 37(3):192-194, 1995

44. Sandhu FS, Dillon WP: Spinal epidural abscess: Evaluation with contrast-enhanced MR imaging. AJNR Am J Neuroradiol 12(6):1087-1093, 1991 
45. Saruhashi Y, Omura K, Miyamoto K, Katsuura A, Hukuda S: A migrated lumbar disc herniation simulating a dumbbell tumor. J Spinal Disord 12(4): 307-309, 1999

46. Schellinger D, Manz HJ, Vidic B, Patronas NJ, Deveikis JP, Muraki AS, Abdullah DC: Disk fragment migration. Radiology 175(3):831-836, 1990

47. Sekerci Z, Ildan F, Yuksel M, Gul B, Kilic C: Cauda equina compression due to posterior epidural migration of extruded lumbar disk. Neurosurg Rev 15(4):311-313, 1992

48. Sengoz A, Kotil K, Tasdemiroglu E: Posterior epidural migration of herniated lumbar disc fragment. J Neurosurg Spine 14(3): 313-317, 2011

49. Şen O, Aydin V, Erdoğan B, Yildirim T, Caner H: Cauda equina syndrome caused by posterior epidural migration of an extruded lumbar disc fragment. Turk Neurosurg 11(3-4):108110, 2001

50. Şenel A, Çokluk C, Çelik F: Posterior epidural migration of extruded lumbar disc mimicking epidural mass: Case report. Turk Neurosurg 13(3-4):115-117, 2003

51. Tarukado K, Tono O, Doi T: Ordinary disc herniation changing into posterior epidural migration of lumbar disc fragments confirmed by magnetic resonance imaging: A case report of a successful endoscopic treatment. Asian Spine J 8(1):69-73, 2014
52. Tatli M, Guzel A, Ceviz A, Karadag O: Posterior epidural migration of sequestered lumbar disc fragment causing cauda equina syndrome. Br J Neurosurg 19(3):257-259, 2005

53. Teufack SG, Singh H, Harrop J, Ratliff J: Dorsal epidural intervertebral disk herniation with atypical radiographic findings: Case report and literature review. J Spinal Cord Med 33(3): 268-271, 2010

54. Walsh AJ, Martin Z, McCormack D: Cauda equina syndrome secondary to posterior epidural migration of a lumbar disc fragment: A rare phenomenon. Eur J Orthop Surg Traumatol 14: 30-31, 2004

55. Watanabe N, Ogura T, Kimori K, Hase H, Hirasawa Y: Epidural hematoma of the lumbar spine, simulating extruded lumbar disk herniation: Clinical, discographic, and enhanced magnetic resonance imaging features. A case report. Spine (Phila Pa 1976) 22(1):105-109, 1997

56. Wiltse LL, Fonseca AS, Amster J, Dimartino P, Ravessoud FA: Relationship of the dura, Hofmann's ligaments, Batson's plexus, and a fibrovascular membrane lying on the posterior surface of the vertebral bodies and attaching to the deep layer of the posterior longitudinal ligament. An anatomical, radiologic, and clinical study. Spine (Phila Pa 1976) 18(8): 1030-1043, 1993

57. Yamashita K, Hiroshima K, Kurata A: Gadolinium-DTPAenhanced magnetic resonance imaging of a sequestered lumbar intervertebral disc and its correlation with pathologic findings. Spine (Phila Pa 1976) 19(4):479-482, 1994 